\title{
STRATEGI PRAGMATIK BAHASA HUMOR DALAM ACARA “MARIO TEGUH GOLDEN WAYS” DI METRO TV
}

\author{
Enie Hendrajati \\ UPM Soshum, Institut Teknologi Sepuluh Nopember, Surabaya, 60111 \\ enie@mku.its.ac.id
}

Diterima: 05 Juni 2017

Direview: 12 Juni 2017

Diterbitkan: 30 Juni 2017

Hak Cipta @ 2017 oleh Penulis (dkk) dan Jurnal Sosial Humaniora (JSH)

*This work is licensed under the Creative

Commons Attribution International License (CC BY 4.0).

http://creativecommons.org/licenses/by/4.0/ Open Access
Subject Areas: Linguistict, arts

\begin{abstract}
Speech humor in MTGW program is assumed as a "good practice" of pragmatic strategy to entertain, inspire and motivate audience. The focus and objective of this study is to get a description of the pragmatic strategy of harmonizing word choice, sentence, and humorous language in MTGW program. This research uses desciptive qualitative approach. Data in the form of humorous languages is collected by listening and recording. The method of analysis is padan and agih. The pragmatic strategy MT uses in the MTGW program on Metro TV is to harmonize between lingual units of words, sentences, and language styles with humor and courtesy. MT uses a locusive and illocusive strategy with humorous tones and politeness in choosing, organizing and producing every word, sentence, and style of humor. Through the choice of words, sentences, and language style, the MT uses pragmatic strategies in conveying his message as a motivator and the perlocutionary effect is that the audience becomes interested or entertained
\end{abstract}

Keywords: pragmatic strategy; types of humorous language; contexts; harmonizing; politeness.

\section{Pendahuluan/Latar Belakang}

Suasana acara "Mario Teguh Golden Ways" (MTGW) di Metro TV terlihat menghibur dan menyenangkan audiennya. Mereka terlihat dan terdengar sering tersenyum, tertawa, dan tepuk tangan, mengisyaratkan mereka "krasan" dan senang mengikuti dan menerima pesan-pesan yang dituturkan Mario Teguh (MT).

Bahasa humor yang dituturkan MT dalam acara MTGW diduga menjadi faktor yang menyebabkan mereka merasa senang dan terhibur. Tuturan humornya berfungsi seperti tontonan yang menyenangkan, sekaligus sebagai tuntunan yang mendidik dan mencerahkan audien karena MT memang berprofesi sebagai motivator dan konsultan. Tuturan humor dalam acara MTGW tersurat dan tersirat pesan-pesan berupa ajaran, dorongan atau motivasi, dan filosofi hidup. Hal ini dapat dibuktikan atau disimak dari topik yang menjadi materi paparan MT pada setiap acara MTGW, di antaranya: Mantanku Penyiksaku, Saya Plus Tuhan Sama dengan Cukup, Jangan Hanya Jadi Wayang, Berani Itu Ajaib, Jalan Menuju Kecemerlangan. Ketika MT menyampaikan materi tersebut di Mitro TV, audien yang berada di hadapannya sering meresponnya dengan senyuman, tawaan, dan tepuk tangan karena materi tersebut disampaikan kepada audiennya disertai dengan tuturan humor. Tuturan humor dalam acara MTGW dapat dimaknai sebagai usaha MT untuk memperindah suasana dengan memperlunak sisi tajam dalam kehidupan manusia (Suprana, 2013). 
Berdasarkan kenyataan bahwa tuturan humor dapat berkorelasi positif dengan respon senyuman, tawaan, dan tepuk tangan audien maka tidaklah berlebihan apabila tuturan humor dalam acara MTGW merupakan "praktik baik" karena terlihat menghibur dan mendidik audien mitra tuturnya. Dengan demikian penelitian ini bermanfaat apabila dapat menghasilkan deskripsi tentang bagaimana MT menggunakan strategi pragmatik dalam memproduksi bahasa humor dalam acara MTGW di Metro TV. Berdasar hal tersebut, fokus dan tujuan penelitian ini memperoleh deskripsi tentang strategi pragmatik penyerasian pilihan kata, kalimat, dan gaya bahasa pada tuturan humor dengan konteks acara MTGW. Bagaimana strategi pragmatik berimplikasi pada pemakaian kata, kalimat, dan gaya bahasa yang dapat merangsang audien mitra tuturnya tersenyum, tertawa, dan tepuk tangan pertanda mereka senang dan terhibur.

Penelitian ini menggunakan pendekatan deskriptif-kualitatif. Data berupa transkripsi tuturan humor dalam acara MTGW dikumpulkan dengan cara simak dan catat. Metode analisisnya adalah metode padan dan agih. Data kata, kalimat, dan gaya bahasa humornya dihubungkan dan dibandingkan dengan kata lain, kalimat lain, dan gaya bahasa lain untuk membandingkan kelucuan antara kalimat yang diproduksi dan kalimat pembandingnya

\section{Strategi Pragmatik dan Tuturan Humor}

Audien acara MTGW di Metro TV sering terlihat dan terdengar tersenyum, tertawa, dan tepuk tangan sebagai isyarat MT menggunakan tuturan humor dalam menyampaikan materi tuturannya. Mengutip pendapat Provine, Anastasya (Anastasya, 2013) menyatakan bahwa humor sangat berkaitan dengan respon tertawa. Wijana (Yuniawan, 2005), tersenyum dan tertawa merupakan indikator yang paling jelas bagi terjadinya penikmatan humor walaupun tidak semua senyuman dan tawaan merupakan akibat dari humor. Claire (Yuniawan, 2005) menambahkan bahwa humor dapat membuat orang tertawa apabila mengandung satu atau lebih dari empat unsur, yaitu kejutan, yang mengakibatkan rasa malu, ketidakmasukalan, dan yang membesar-besarkan masalah. Keempat unsur itu dapat terealisasi melalui komunikasi dan rangsangan verbal berupa satuan lingual yang sengaja dikreasi oleh penutur dan/atau petuturnya. Rakhmat (Rakhmat, 1992) menyatakan kita tertawa bila menyaksikan sesuatu yang janggal, keliru atau cacat. Objek yang membuat kita tertawa adalah objek yang aneh, ganjil dan menyimpang. Humor timbul karena kita menemukan hal-hal yang tidak terduga atau kalimat (juga kata) yang menimbulkan dua macam asosiasi”.

Sebagai motivator, MT memanfaatkan tuturan humor untuk melakukan dua hal: (1) MT melakukan penilaian, kritikan, ajakan, larangan; (2) MT melalui tuturan humornya juga menyampaikan ide atau solusi, kadang-kadang secara terang-terangan, tapi kadangkala dengan tuturan humor ilustratif dalam memotivasi dan menginspirasi mitra tuturnya terkait dengan nilai-nilai kehidupan. Dengan dan dalam melakukan dua hal tersebut, MT memanfaatkan tuturan humor sehingga audien acara MTGW terlihat dan terdengar tersenyum, tertawa, dan tepuk tangan.

Respon tersenyum, tertawa, dan tepuk tangan audien dalam acara Metro TV itu dapat diduga sebagai implikasi dari realisasi strategi pragmatik. Bagaiman menjelaskan secara konseptual-teoretik tentang hubungan antara strategi pragmatik, tuturan humor, dan respon tersenyum atau tertawa?

Dalam suatu peristiwa tutur, seperti acara MTGW antara MT sebagai penutur dengan audien 
mitra tutur perlu saling berpedoman pada prinsip kerja sama (Oka, 1993) agar proses komunikasi berjalan dengan baik. Yule (Wahyuni, 2006) berpendapat bahwa bentuk kerja sama menjadi prinsip interaksi karena orang-orang yang terlibat umumnya tidak diasumsikan untuk berusaha menyesatkan, mempermainkan atau menyembunyikan informasi yang relevan.

Prinsip kerja sama bersifat mengatur, bukan sebagai unsur yang bersifat konstitutif (Oka, 1993). Dengan demikian untuk mencapai tujuan tertentu maka penutur atau petutur bisa melanggar prinsip kerja sama. Penutur bisa melanggar prinsip kualitas, misalnya berbohong, tidak terbuka atau terus terang kepada mitra tuturnya karena alasan kesantunan atau kesopanan. Dalam masyarakat kita, budaya komunikasi untuk tidak mengutarakan makna, maksud, atau pesan secara terbuka, terang-terangan atau "blak-balakan" dalam konteks tertentu masih menggejala dengan alasan aspek kesantunan. Prinsip kuantitas juga bisa dilanggar, misalnya dengan mengurangi atau melebih-lebihkan makna atau pesan kepada mitra tuturnya. Tujuannya bisa untuk berhumor, bersopan-santun, atau untuk tujuan lainnya. Jadi, pelanggaran prinsip kerja sama tersebut bisa karena dipengaruhi faktor budaya. Bahasa merupakan bagian dari budaya.

Strategi pragmatik, tindak tutur, dan budaya tidak terpisah walupun bisa dibedakan. Budaya menurut Lado (Tarjana, 2016) merupakan "structured systems of patterned behaviour," karena itu dalam berbahasa pun orang dapat mengidentifikasi model dan pola perilaku kolektif masyarakat dalam bertindak tutur karena bahasa dan model berbahasa memang sebagai bagian dari sistem budayanya. Dengan demikian, bahasa tidak bisa berdiri sendiri lepas dari konteks sosial dan budaya.
Penggunaan bahasa bersifat context-dependent, terikat konteks sosial, budaya, situasi, dan kondisinya. Ilustrasinya, menyapa mitra tutur dengan menggunakan pronomina persona kamu, anda, saudara, bapak atau ibu wajib mempertimbangkan faktor tradisi sosial-budaya masyarakatnya.

Pertanyaannya, bagaimana MT bisa menyampaikan materi tuturnya dalam acara MTGW dengan tuturan homor yang membuat audiennya merespon dengan senyuman, tawaan, dan tepuk tangan? Faktor pengalaman pragmatik, kompetensi pragmatik, dan strategi pragmatik yang ada pada diri penutur akan mempengaruhi keefektifan suatu tuturan, termasuk tuturan humor oleh MT yang terbukti menimbulkan respos tersenyum, tertawa, dan tepuk tangan dari audiennya.

Gunarwan (Gunarwan, 1997) menggunakan terminologi "kompetensi pragmatik" dalam pengertian kefasihan dalam berbahasa atau berbicara. Seseorang yang tidak fasih dalam berbahasa atau berbicara dianggap tidak memiliki kompetensi pragmatik dalam bahasa tersebut. Baskoro (Baskoro, 2014) juga mengatakan bahwa pelaku tutur yang memiliki kemampuan menghasilkan dan memahami tindak komunikatiflah yang dikategorikan memiliki kompetensi pragmatik.

Berdasarkan pendapat tersebut dapat dikatakan bahwa kompetensi pragmatik mengacu pada kemampuan menggunakan bahasa dalam komunikasi dengan fasih, lancar, dan efektif. Pengertian kompetensi pragmatik kurang lebih sama dengan pengertian kompetensi komunikasi, yaitu kemampuan menggunakan bahasa (kata, kalimat, dan gaya bahasa) sesuai atau serasi dengan konteks: dengan siapa, kapan, di mana, dan untuk tujuan apa. Kata kuncinya adalah kepantasan dan kepatutan. 
Tuturan humor, respon tersenyum, tertawa, dan strategi pragmatik berkorelasi positif. Senyum atau tawa adalah reaksi mitra tutur terhadap kata, kalimat, dan gaya bahasa yang digunakan penutur dalam tuturan humor. Bahasa pada tuturan humor membuahkan efek tersenyum dan tertawa karena satuan lingual yang digunakan serasi dengan peristiwa atau keadaan yang dihadapinya (Keraf, 2000) (Alwi dkk., 2003). Tuturan humor yang dibentuk dari pilihan kata, kalimat, dan gaya bahasa yang tepat dan serasi dengan acara atau keadaan ketika acara itu berlangsung adalah tuturan yang dibangun berdasarkan strategi pragmatik. Maksudnya, penutur menggunakan strategi pragmatik atau tidak akan tampak dari reaksi selanjutnya, berupa aksi verbal maupun berupa aksi nonverbal dari audien mitra tuturnya.

Ilustrasi sederhana, calon menantu tidak menggunakan strategi pragmatik apabila menyapa calon mertuanya dengan sapaan kamu, anda, atau saudara. Kata-kata itu tidak pantas, tidak sopan, atau tidak sesuai/tidak serasi/tidak cocok digunakan oleh orang muda apalagi oleh calon menantu kepada calon mertua. Jadi, kata "keserasian" sebagaimana terdapat dalam fokus penelitian mengacu pada kesesuaian pemakaian satuan lingual dengan konsteks sosial budaya yang lazim digunakan sebagai pedoman dalam bertindak, termasuk dalam bertindak tutur.

DeVito (De Vito, 1977) menyatakan bahwa komunikasi adalah proses penyesuaian, komunikasi berdimensi isi dan hubungan, komunikasi melibatkan traksaksi simetris dan komplementer, komunikasi paket isyarat. Prinsip yang relevan dengan fokus penelitian ini adalah prinsip komunikasi sebagai proses penyesuaian karena pada dasarnya tidak ada dua orang yang menggunakan sistem isyarat yang persis sama. Apabila sistemnya berbeda, komunikasi yang bermakna dan efektif tidak akan terjadi.

DeVito juga mengatakan bahwa sebagian dari seni komunikasi adalah kemampuan pelaku tutur untuk mengidentifikasi isyarat-isyarat yang dikomunikasikan mitranya, mengenali bagaimana isyarat-isyarat itu digunakan, dan memahami apa makna dan maksudnya. Mereka yang sudah kenal atau bersahabat akan menyadari bahwa mengenali isyarat-isyarat orang lain memerlukan waktu lama. Jika ingin benar-benar memahami apa yang dimaksud mitra tutur, bukan sekedar mengerti apa yang dikatakan tetapi perlu mengenal sistem isyarat yang digunakan mitranya. Tujuannya agar ada kesesuaian atau penyerasian antara kedua belah pihak tentang sistem isyarat tersebut sehingga proses untuk mengerti, memahami makna atau maksud pesannya menjadi mudah.

Tersenyum, tertawa, dan tepuk tangan pun akan dilakukan oleh pelaku tutur apabila kedua belah pihak saling mengerti atau memahami makna dan maksud pesannya (berada dalam dunia makna yang sama). Persyaratan untuk itu adalah prinsip bahwa komunikasi adalah penyesuaian atau penyerasian antar pelaku tutur tentang sistem isyarat yang digunakan.

Penelitian tentang humor dalam kaitannya dengan budaya, filosofi, linguistik, dan psikologi sudah pernah dibahas (Sinkeviciute \& Dynel, 2017). Penelitian teoretis tersebut menganggap bahwa humor merupakan fenomena universal yang menunjukkan mekanisme dan kateristik yang sama pada lintas bahasa dan budaya. Yang sering digunakan dalam konteks budaya atau kultur yang berbeda adalah humor yang muncul dari interaksi antar anggota keluarga dan teman sebaya, dan humor dikarakteristikan sebagai ikatan yang dapat 
meningkatkan keakraban dan menunjukkan ketertarikan. Humor, ketertarikan, dan keakraban berkaitan erat.

Penelitian lain membahas tentang humor dalam kaitannya dengan komunitas penderita kangker. Komunikasi sehat melalui humor menciptakan keakraban, perasaan senasib, kesetiakawanan, dan proses penyemangatan, pemberdayaan (Demjén, 2016). Humor sebagai jenis permainan mental yang melibatkan hal-hal yang riang, sikap tidak serius terhadap ide dan peristiwa. Mengaitkan humor dengan kegembiraan atau keriangan, kesetiakawanan, pemberdayaan, dan kesehatan. Tuturan humor dengan unsur satuan lingual kata, kalimat, dan gaya bahasa yang mencerminkan tindak ilokusi dan perlokusi yang menyehatkan karena atmosfer yang terbentuk adalah keriangan, kesukariaan, kesetiakawanan, dan penyemangatan atau pemberdayaan.

Penelitian lain yang relevan dengan penelitian ini adalah yang dilakukan Gunarwan (Gunawan, 1997). Temuannya antara lain adalah ada isyarat bahwa orang Jawa Jakarta cenderung menilai tindak tutur melarang tanpa basa-basi itu lebih sesuai daripada orang Jawa yang berdomisili di daerah Jawa. Jadi, orang Jawa Jakarta mulai meninggalkan norma Jawa mereka. Dari aspek atau variabel gradasi umur dan pendidikan juga demikian. Ada isyarat (lemah) bahwa penilaian responden atas kepatutan tindak tutur melarang tanpa basa-basi berkorelasi menurut tingkat pendidikan dan gradasi umur.

Berdasarkan paparan beberapa hasil penetian dan prinsip komunikasi itu dapat disimpulkan bahwa komunikasi atau tindak tutur adalah proses penyerasian atau penyesuaian. Gaya dan bentuk tuturan diserasikan dengan siapa audien mitra tuturnya, dengan tempat tuturan itu digunakan, dengan tujuan tuturan, dan dengan waktu berlangsungnya. Tanpa ada penyerasian, misalnya karena pelaku tuturnya tidak fasih, anak kecil, orang asing, atau orang gila maka tuturan humornya tidak akan direspon mitra tuturnya dengan senyuman, tawaan, dan tepuk tangan, dan itu pertanda bahwa pelaku tuturnya tidak memiliki kompetensi pragmatik dan strategi pragmatik.

Teori Goffman yang dielaborasi oleh Brown dan Levinson (Brown dan Levinson, 1987) menjelaskan juga tentang pentingnya penyerasian antara tuturan santun dan proses penyelamatan muka pelaku tutur (FTA/Face Threatening Acts). Hal ini karena secara kodrat setiap orang punya muka atau harga diri yang wajib selalu dijaga, dipelihara, dan dihormati oleh setiap pelaku tutur. Tesis dasar teori tuturan santun adalah bahwa setiap pelaku tutur akan "menghitung" derajat keterancaman tindak tuturnya dengan mempertimbangkan (1) jarak sosial/tingkat keakraban antara penutur dan lawan tuturnya, (2) jarak kuasa antara penutur dan lawan tuturnya. Karena ada peluang muka pelaku tutur untuk terancam maka mereka selalu menggunakan strategi dalam melakukan tindak tutur, meliputi: (1) strategi bertutur langsung, tanpa basa-basi, terang-terangan, (2) strategi bertutur dengan menggunakan kesantunan positif untuk menunjukkan keakraban atau hubungan baik antara keduanya, (3) strategi bertutur dengan menggunakan kesantunan negatif untuk menunjukkan jarak sosial antara keduanya, (4) strategi bertutur secara tidak langsung/samar-samar, dan (5) strategi diam, tidak melakukan tuturan. Semua strategi tersebut berdasar pada prinsip komunikasi bahwa interaksi atau komunikasi adalah proses penyesuaian. Penelitian ini menggunakan istilah penyerasian dan penyesuaian dalam pengertian yang relatif sama dan berkaitan. 
Penggunaan satuan lingual kata dan kalimat dalam kegiatan bertutur, seperti dalam acara MTGW di Metro TV tidak bisa dipisahkan dengan konteks. Guy Cook (Eriyanto, 2001) berpendapat bahwa bahasa tidak bisa diposisikan sebagai mekanisme internal dari linguistik semata; bahasa bukan suatu objek yang diisolasi dalam ruang tertutup. Bahasa perlu dipahami dalam konteks secara keseluruhan. Dalam hal ini, Guy Cook menyebut tiga hal penting, yaitu teks, konteks, dan wacana. Teks adalah semua bentuk bahasa, selain berupa kata, kalimat, juga termasuk semua jenis ekspresi komunikasi, ucapan, efek suara, citra, dan sebagainya. Konteks adalah situasi dan hal yang berada di luar teks dan mempengaruhi pemakaian bahasa, seperti partisipan, tempat, dan waktu. Wacana, kemudian dimaknai sebagai teks dan konteks bersama-sama.

Sudaryanto (Sudaryanto, 1985) tidak menggunakan terminologi konteks, tetapi lingkungan. Dia mengatakan bahwa lingkungan merupakan faktor yang sangat mempengaruhi penggunaan bahasa. Gejala berbahasa yang memiliki ciri-ciri khas dapat diamati dalam lingkungan tertentu. Contohnya, bahasa dalam lingkungan keluarga, yang di situ terdapat ayah, ibu, dan anak. Bagaimana bahasa anak ketika pengalaman pertamanya di sekolah kepada ibunya, kemudian ditanggapi oleh ayah dan kakaknya. Demikian pula bila lingkungan atau konteksnya di pasar. Di situ terdapat bahasa tawar-menawar dan jika tawaran disetujui terjadi pembayaran dan mungkin juga pengembalian uang. Semua lingkungan itu akan mempengaruhi penutur dan petuturnya dalam memilih dan menggunakan satuan lingual berupa kata, kalimat, dan gaya bahasanya. Dengan dasar pendapat dan pandangan tersebut maka faktor penting dalan tindakan bertutur adalah kesesuaian atau keserasian antara konteks atau lingkungan dengan pilihan kata, kalimat, dan gaya bahasa.

Contoh yang menguatkan pandangan bahwa keserasian antara satuan lingual kata dan kalimat dengan konteks merupakan keniscayaan adalah penggunaan pronomina persona. Alwi dan temantemannya. (Alwi dkk, 2003) menyebut tiga parameter yang menjadi dasar penyerasiannya, yaitu (1) umur, (2) status sosial, dan (3) keakraban. Pronomina saya lebih umum dipakai daripada $a k u$ oleh orang muda terhadap orang tua. Untuk menunjukkan rasa hormat, pronomina beliau dipakai alih-alih dia. Sebaliknya, orang tua merasa senang memakai sapaan adik atau mas daripada kamu bila menyapa orang muda yang tidak begitu dikenalnya atau yang bukan bawahannya.

Status sosial, misalnya seorang kepala suatu instansi dapat memakai pronomina kamu apabila mitra tuturnya pegawai bawahannya, apalagi jika usianya lebih muda. Sebaliknya, ia akan menggunakan kata Saudara atau Bapak jika mitra tuturnya tamu yang sebaya, baik umur maupun status sosialnya. Demikian pula seorang pegawai akan merasa lebih pantas dan patut jika ia menyapa atasannya dengan kata bapak atau ibu.

Parameter keakraban dapat menyilang garis pemisah umur dan status sosial walaupun hanya dalam situasi tertentu. Penutur A dan B umurnya relatif sama, keduanya berteman sangat akrab karena sejak studi di SD dan SMP selalu satu sekolah. Hanya, nasib atau status sosialnya berbeda. Penutur A menjadi bawahan B. Dalam situasi formal, misalnya dalam forum rapat, A dapat menyapa atasannya dengan tuturan (a) Jika saya boleh tahu, pandangan Bapak dalam soal ini bagaimana? Sebaliknya, pada acara reuni, pantas saja apabila A berkata kepada B atasannya itu dengan kata, kalimat 
dan gaya bahasa seperti tuturan (b) Hei, kamu biasanya suka sekali makan sate, kenapa sekarang sate-sate ini dibiarkan tidak kamu santap. Sekali-kali tidak apa-apa lur.

Berdasarkan gambaran di atas dapat dikatakan bahwa suatu tindak tutur perlu memperhatikan dimensi hubungan, selain dimensi isi. Oleh karena itu, penggunaan kata, kalimat, dan gaya bahasa dalam kegiatanm komunikasi perlu memperhatikan keserasian dan kesesuaian dengan konteks pemakaiannya; jika tanpa mempedulikan keserasian tersebut dapat meninbulkan hal yang mengganggu keserasian hubungan. Penggunaan kata saya, kamu, bapak, anda, hei, karena diprovokasi oleh konteks atau merupakan cerminan konteks. Kontekslah yang menuntut penutur memilih dan menggunakan satuansatuan lingual kata, kalimat, dan gaya bahasa.

Faktor yang mendorong proses pemilihan dan penggunakan satuan lingual kata dan kalimat dalam suatu tindak tutur tidak bersifat tunggal. Penutur memilih menggunakan kata dan kalimat ragam baku atau nonbaku bukan semata-mata karena faktor situasi formal saja; bisa juga karena faktor mitra tutur atau audiennya dari kalangan dengan status sosial tinggi. Demikian pula jika penutur menggunakan kata dan kalimat dalam ragam bahasa humor maka faktor waktu, tempat, situasi, faktor mitra atau audien petutunya akan ikut mempengaruhinya. Faktorfaktor tersebut bisa saja memiliki kedudukan yang tidak sama pentingnya. Dalam masyarakat bangsa Indonesia, khususnya masyarakat yang berbudaya Jawa faktor partisipan, yaitu siapa berbicara dengan siapa cenderung merupakan faktor lebih penting daripada faktor lainnya.

Pemilihan satuan lingual dalam kegiatan komunikasi tidak bersifat acak, melainkan cenderung diserasikan dengan faktor pemakai dan pemakaiannya. Antara pemakai dan pemakaian bahasa berkaitan erat. Keserasian atau kesuaian antara siapa penuturnya dengan: (a) apa yang menjadi topik tuturan, (b) siapa mitra atau lawan tuturnya, (c) kapan atau dalam situasi dan kondisi seperti apa tuturan itu dilaksanakan, (d) di mana tuturan berlangsung, (e) dengan media apa, dan (f) untuk tujuan apa tuturan itu dilakukan merupakan faktor penting yang perlu diserasikan dalam kegiatan bertutur.

Sekilas tampak terasa seperti tidak mudah untuk menyerasikan dan menyesuaikan antara pemakai bahasa dan pemakaiannya. Akan tetapi, jika memperhatikan bagaimana seseorang memperoleh dan mempelajari bahasa pertama yang melalui jangka waktu bertahun-tahun dengan tahap demi tahap dalam proses pemerolehannya yang penuh perjuangan maka wajarlah apabila penutur bahasa dalam memilih bahasa dan/atau variasi bahasa yang tepat tidak menemui kesulitan yang berarti. Hal ini karena proses internalisasi sistem bahasa dan sistem pemakaian bahasanya berproses dalam diri pembelajar bahasa tersebut dalam jangka waktu yang relatif lama (pengalaman pragmatik) sehingga akhirnya dapat menjadi kebiasaan dan membentuk model perilaku kolektif bertutur yang relatif sama antara anggota masyarakat pemakainya. Dari usia balita seorang penutur suatu bahasa, dari hari ke hari, dari bulan ke bulan dan dari tahun ke tahun dengan penuh perjuangan berpraktik berbahasa sehingga perangkat kebahasaan yang ada pada setiap manusia balita dapat tumbuh berkembang dengan baik sesuai dengan perkembangan usianya sehingga akhirnya terbentuk model perilaku kolektif berbahasa yang relatif sama antar individu dalam masyarakat bahasa yang bersangkutan. 
Pengalaman pragmatik kita sangat menentukan apakah kita bisa memproduksi dan/atau mengkomprehensi tindak tutur (humor) dengan tepat. Tindak tutur sering kali berupa kolokasi tetap yang terjadi dalam situasi-situasi yang bisa diprediksikan dan karenanya tugas penafsiran yang diemban sang pendengar sering kali tidak berat (Elizabeth Black dalam Ardianto dkk., 2011). Aturan berkomunikasi diperoleh melalui proses internaslisasi dalam waktu yang relatif lama. Aturan berkomunikasi atau berbahasa pada dasarnya sama seperti aturan bermain sepak bola atau aturan berlalu lintas. Aturan itu sama-sama perlu diketahui, dimengerti, dan dijadikan pedomannya sehingga kegiatan bermain bola, berlalu lintas, dan berbahasa menjadi lancar.

Dalam pemilihan bahasa untuk kegiatan bertutur atau berkomunikasi terdapat tiga kategori pilihan. Pertama, dengan memilih satu variasi dari bahasa yang sama. Apabila seorang penutur bahasa Indonesia berbicara kepada audien dengan menggunakan ragam bahasa (Indonesia) humor maka ia telah melakukan pilihan bahasa kategori pertama ini. Kedua, dengan melakukan alih kode, artinya menggunakan satu bahasa untuk satu tujuan dan menggunakan bahasa yang lain untuk tujuan lain dalam satu peristiwa tutur. Ketiga, dengan melakukan campur kode, artinya menggunakan satu bahasa tertentu bercampur dengan bahasa lain.

\section{Hasil Dan Pembahasan}

\section{A. Penyerasian Pilihan Kata dengan Humor} dan Kesantunan sebagai Strategi Pragmatik

Pilihan kata oleh MT menjadi lucu dan diterima oleh audien karena beberapa hal. Pertama, MT memilih dan menggunakan kata dengan daya ilokusi yang tepat. Kata yang digunakan selain memiliki hubungan makna yang serasi dengan kata lain dalam satu kalimat, juga memiliki keserasian dengan humor dan kesantunan.

Sebagai motivator, MT melalui ragam humor melakukan penilaian, kritikan, nasihat, dan ajakan dengan kata-kata dengan makna dan maksud yang mudah dipahami audiennya. Pilihan kata-kata dalam ragam bahasa humornya, selain membuat audiennya mudah mengerti makna dan maksudnya dengan jelas, juga nadanya tegas, dan kadang-kadang keras. Terkadang MT menggunakan hubungan medan makna, antonimi, dan sinonimi untuk mempertegas pesannya. Penggunaan kata-kata tegas dan kadangkadang keras tetapi tidak bernada mengancam harga diri/muka mitranya karena kata-kata tegas, keras tersebut bernuansa lucu dan santun. Kekuatan pilihan kata dalam ragam bahasa humornya tampak pada kombinasi yang serasi antara kata yang daya ilokusinya tegas, keras, jelas, lucu, dan sesuai dengan norma-norma kesantunan.

Kata-kata yang dipilih dan digunakan MT dalam bahasa humor acara MTGW berupa pronomina persona kita, anda, bapak/ibu; adjektiva, verba, dan nomina. Bukan berarti jenis kata yang lain tidak digunakan, tetapi penelitian ini membatasinya pada jenis kata-kata tersebut. Contoh teks:

\section{Teks 1}

Kalau tidak ada mantan tidak tersiksa ya? Waktu pacaran menderita karena pacar, setelah putus, kebahagiaan mantan menyiksa kita. Audien terdengar tertawa. Waktu bersamasama tersiksa, setelah terpisah memperhatikan untuk tersiksa. Kita ini tidak bisa jauh dari sikap kita sebagai bayi. Bayi itu kalau mainannya atau mantannya dibuang, diambil bayi lain, marah. Kita sama. Sudah putus, tapi tidak ikhlas melihat sahabat kita mengambil mantan kita. Audien terdengar tertawa.Ya, seperti ada hak guna bangunan, gitu. Itu, untuk para mantan. Audien terdengar tertawa.

Pemakaian pronomina persona kita pada teks bersifat inklusif. Mengisyaratkan bahwa MT dan audiennya berada dalam kelompok yang sama (in- 
groupness), yaitu kelompok manusia yang memiliki sifat yang sama dalam menyikapi mantan; samasama merasa tersiksa jika melihat mantan bahagia, sama-sama tidak bisa jauh dari sikap sebagaimana bayi, sama-sama tidak ikhlas melihat sahabat mengambil mantan kita; mencakup semua manusia. "Ketidakikhlasan" melihat mantan bahagia dan diambil sahabat atau orang lain bersifat generaluniversal. Penyamarataan bahwa semua manusia akan bersikap sama dalam menghadapi sang mantan, yaitu sikap: "mantanku adalah penyiksaku."

Teks humor (Teks 1) merupakan pembukaan atau pendahuluan sehingga wajar tuturannya bernada keheranan, kegemasan, dan kejenakaan terhadap sifat universal manusia. Tuturan pembuka yang provokatif-metaforik, tanpa menyinggung, menyakiti, dan mengancam muka audien atau siapa pun karena pronomina kita dalam teks itu tidak menunjuk pada orang per orang, tetapi menunjuk pada semua manusia.Kesannya terasa menyamaratakan secara berlebihan (teknik humor exaggeration), tapi justru itulah yang menimbulkan efek jenaka dan tawa bagi audiennya.

Pada teks (Teks 1), MT menggunakan verba perbuatan: menyiksa, memperhatikan,dan mengambil. Verba perbuatan ini digunakan MT untuk menjelaskan secara hiperbolik-provokatif kepada audien dan kita semua bahwa setiap manusia ada kecenderungan tidak ikhlas dalam menyikapi sang mantan. Ketidakikhlasannya dituturkan oleh MT dengan penggunaan verba perbuatan yang berkesan aneh atau ganjil sehingga menimbulkan kelucuanatau kejenakaan.
(a) ...kebahagiaan mantan menyiksa kita;
(b) ...setelah terpisah memperhatikan untuk tersiksa;
(c) ...tidak ikhlas melihat sahabat kita mengambil mantan kita;

(d) ...begitu putus seperti orang jahat, mendoakan supaya dia gagal.

Kata menyiksa (karena melihat kebahagiaan mantan) bermakna 'berbuat bengis dengan cara menyengsarakan, menganiaya atau menyakiti' diri kita sendiri; keanehan yang menimbulkan kejenakaan. Kata mendoakan (supaya dia gagal) dalam cuplikan tutur (d) rasanya "aneh dan menggelikan". Jika benar demikian maka sangat egois dan dengkinya manusia terhadap sang mantan hingga manusia melakukan perbuatan "berdoa" agar mantannya gagal. Demikian pula kata memperhatikan (sang mantan) untuk membuat diri kita sendiri tersiksa. Pemakaian verbal perbuatan seperti itu merupakan manifestasi dari sifat universal manusia, walaupun berdasarkan nalar rasa dan rasio bercorak memprovokasi mitra tuturnya. Aneh, jenaka tapi nyata, dan MT “mengemas" yang aneh tapi nyata itu dengan satuan-satuan bahasa yang berdaya ilukosi sentuh sehingga rasa kejenakaan tutur humornya bukan saja berkategori tontonan humor, tetapi juga tuntunan. Demikian pula dengan pemakaian pronomina anda dan adjektiva dapat disimak pada contoh teks (2) berikut ini.

Teks 2

So, sahabat-sahabat saya yang baik hatinya. Kesimpulan dalam program ini. Kalau tidak untuk Anda memang tidak untuk Anda. Itu harus diterima dengan ikhlas. Kalau tidak untuk saya tidak akan untuk saya. Tapi kalau untuk Anda walaupun Anda memutuskan untuk move away, move on, atau move up, dia jadi. Tapi dibutuhkan dari kita adalah ketegasan untuk menghormati diri. So, sahabat-sahabat saya yang baik hatinya. Memang masalah cinta tidak pernah selesai karena setelah menikah pun itu masalahnya menjadi lebih berat. Anda harus jatuh cinta kepadanya tiap hari. Padahal dia tambah hari tambah berat. MT dan audien terdengar tertawa ramai. Iya toh? Bajunya tambah lama tambah lebar, lalu dia meminta kita mencintainya seperti dia masih cantik, centil, ranum yang jalannya nggak sampai-sampai. Audien terdengar tertawa ramai. Hayo, jangan Anda pikir cinta remaja itu berat. Cinta orang yang sudah menikah, yang sudah tua itu lebih berat lagi. Itu. Audien terdengar tepuk tangan ramai. 
Pemakaian pronomina anda bersifat menetralkan hubungan, seperti kata you dalam bahasa Inggris. Hubungan antara penutur dan petutur tidak terlalu formal dan tidak terlalu akrab. Pronomina anda juga dipakai dalam hubungan takpribadi sehingga kata tersebut tidak diarahkan pada satu orang khusus (Alwi, dkk., 2003:253). Konteks sistem sosial budaya masyarakat Indonesia masih membatasi pemakaian kata anda karena perhatian bangsa kita terhadap tata krama dalam pergaulan masih belum berkurang (Alwi, 2003:253).

MT dalam acara MTGW di Metro TV relatif sering menyapa mitra tuturnya dengan kata anda. Penggunaan pronomina anda oleh MT dalam acara MTGW dengan fungsi menetralisasi hubungan dengan audiennya. MT sebagai penutur menempatkan audienya sederajad dengan dirinya. Audien MTGW tidak direndahkan, misalnya dengan menggunakan sapaan kamu atau engkau kepada audien.

Dengan pemakaian pronomina anda seperti itu maka keformalan, kekakuan dan kecanggungan hubungan interpersonal antara MT dan audien acara MTGW tidak terlihat. Akibat lanjutannya, acara MTGW terlihat berlangsung dalam suasana kekerabatan, persahabatan, keakraban, kesantunan, dan kejenakaan.

Teks 2 merupakan kesimpulan dari materi tuturnya yang bertopik "Mantanku Penyiksaku." Kesimpulannya:

"Kalau tidak untuk Anda memang tidak untuk Anda. Itu harus diterima dengan ikhlas. Kalau tidak untuk saya tidak akan untuk saya. Tapi kalau untuk Anda walaupun Anda memutuskan untuk move away, move on, atau move up, dia jadi."

Setelah MT menyampaikan kesimpulan tersebut kepada audien, kemudian MT mengembangkan simpulan itu dengan pemakaian adjektiva (simak Teks 2) seperti tuturan: (a)...masalah cinta tidak pernah selesai...

(b)... setelah menikah ... lebih berat lagi...

(c)... bajunya tambah lama tambah lebar, lalu dia meminta kita mencintainya seperti dia masih cantik, centil, ranum yang jalannya ngak sampai-sampai.

(d)... jangan Anda pikir cinta remaja itu berat.

(e)... cinta orang yang sudah menikah, yang sudah tua itu lebih berat lagi.

Cuplikan tuturan (a) s.d. (e) berunsur adjektiva (cetak tebal) dan bersifat menilai, tetapi yang dinilai tentang cinta bukan orang. Yang membuat tuturan itu jenaka adalah yang (c) karena makna dan pesan yang akan ditangkap audien mitra tuturnya adalah bahwa istri kita tambah lama tambah "gendut". Cuplikan tutur (c) merupakan sindiran halus dan lucu. Teks 3 di bawah ini mengandung pesan nasihat kepada audien untuk terbiasa ikhlas dalam menyikapi dan merawat cinta.

Teks 4 di bawah ini merupakan contoh data pemakaian adjektiva dalam tuturan humor yang berkonotasi menilai orang per orang.

\section{Teks 3}

MT: Dia masih bilang belum bisa memutuskan. Lihat, berarti mungkin memang dia sendiri harus merasakan dampak dari keputusannya. Tidak ada nasihat bisa membantu orang yang memutuskan buruk bagi dirinya. Audien terdengar tertawa. Lo, kok ketawa. Ini bisa serius lo ya? Di belakang ini ada jam Ibu (MT menunjuk di belakang kepala Bu Ida). Namanya jam biologis dan berlaku sangat serius bagi wanita. Ibu tidak selamanya sesuai untuk melahirkan...... Orang-orang yang meratapi perginya penghianat cinta merasa dirinya pantas untuk dihianati. Hormati diri.

\section{Teks 4}

\begin{abstract}
Wah bahaya ini! Audien dan MT trdengar tertawa. Satu, ingin terkenal itu riak, kesombongan, tidak boleh. Ingin dikenal sebagai orang baik, harus, supaya Anda berpengaruh karena Anda dikenal orang baik. Kalau terkenal, itu tidak harus berkualitas. Anda masuk kandang macan, audien terdengar tertawa, macannya sedang marah sama istrinya. Coba! Audien terdengar tertawa.
\end{abstract}

Teks 3 tuturan MT untuk merespon pernyataan mitra tuturnya (Id) yang sangat setia kepada pacarnya walaupun dihianati berkali-kali. Sedangkan Teks 4 tuturan MT untuk menanggapi lawan tuturnya (Kar) 
yang kurang bisa memahami maksud pilihannya dalam poling sehingga membuat MT menggunakan adjektiva seperti dalam tuturan Teks 4

Teks 3, MT menyampaikan pesan kepada mitranya secara jelas, tanpa basa-basi (bald on record), tapi tidak bernada "menyerang" muka mitra tuturnya secara langsung dan keras. Indikasi bahwa MT memperhatikan kesantunan bertutur. Hal ini ditandai oleh bentuk tuturannya yang bercorak konsepsional-postulaif sehingga pesannya bernilai general-universal, tidak menunjuk pada orang per orang. Brown dan Levinson (dalam Gunarwan, 1992:21) menyebut tindak tutur konsepsional sebagai ketentuan yang bersifat umum. Tuturan:

(a) Untuk menikah yang panjang sampai tua butuh cinta sepenuhnya atau sedikit? Audien menjawab "sepenuhnya."

(b) Tidak ada nasihat bisa membantu orang yang memutuskan buruk bagi dirinya.

(c) Orang-orang yang meratapi perginya penghianat cinta merasa dirinya pantas untuk dihianati.

(d) Ini bisa serius lo ya?

(e) Di belakang ini ada jam Ibu (MT menunjuk di belakang kepala Bu Ida). Namanya jam biologis dan berlaku sangat serius bagi wanita. Ibu tidak selamanya sesuai untuk melahirkan.......

bersifat konsepsional atau postulasi, semacam ketentuan umum. Kata yang dicetak tebal berjenis adjektiva dengan fungsi memerikan kualitas dan intensitas yang bercorak mental. Kata-kata yang digunakan dalam tuturan itu mudah dimengerti, tegas, keras, tapi santun dan bernuansa jenaka. MT menyapa mitra tuturnya dengan nomina penyapa $i b u$, bapak, dan sahabat sehingga kesannya tidak eksplisit mengancam muka mitranya.

Teks 4 pesannya dituturkan dengan jelas, tegas, tanpa basa-basi, dan kritikan eksplisit. Adjektiva riak 'takabur' atau 'sombong', diperjelas dan dipertegas dengan nomina kesombongan, serta adverbia tidak boleh dapat membuat muka mitra tuturnya terancam.
Menilai dan melarang secara langsung terhadap orang yang diajak bicara secara tegas dan eksplisit di hadapan orang banyak/audien, apalagi disaksikan oleh publik pemirsa acara MTGW adalah suatu tindak tutur yang derajat kesantunannya rendah. Hal ini karena kritikannya bersifat langsung dengan menggunakan kata-kata kasar (Chaer, 2010). Adjektiva riak dan sombong merupakan contoh kata yang kasar; adverbia tidak boleh adalah bentuk melarang secara langsung dan eksplisit. Akan tetapi beban keterancaman muka mitranya dapat berkurang dengan tuturan humor, seperti:

"Kalau terkenal, itu tidak harus berkualitas, Anda masuk kandang macan, macannya sedang marah sama istrinya."

Pada acara MTGW, MT juga memanfaatkan nomina yang difungsikan sebagai ilustrasi atau eksemplifikasi. Kita simak cuplikan teks (a) s.d. (g) berikut ini.

(a) Kita ini tidak bisa jauh dari sikap kita sebagai bayi. Bayi itu kalau mainannya, mantannya dibuang, diambil bayi lain, marah.

Nomina bayi, cuplikan (a) atau Teks 1 digunakan MT sebagai ilustrasi dengan fungsi memberi penjelasan kepada audien tetang kecenderungan manusia pencemburu terhadap mantannya diibaratkan seperti bayi: cengeng, tidak dewasa, tidak mandiri, dan mudah menangis.

Apakah penggunaan kata bayi seperti itu berasa mengancam muka audien mitra tuturnya? Jawabannya, tidak. Konotasi kata bayi: ingusan dan cengeng, dan mudah menangis terasa sebagai sindiran ironis dan "nylekit." Akan tetapi, konotasi tersebut tidak mengancam muka mitra tuturnya bahkan justru memberi kesan lucu atau jenaka. Hal ini karena kata atau sifat "kebayi-bayian" ditujukan pada kita atau semua manusia, bukan pada orang per orang. Selain itu, MT menegaskan (tegas dan kasar 
berbeda) kepada publik pemirsa MTGW bahwa sifat dan sikap cemburu terhadap mantan adalah salah walaupun sifat cemburu merupakan keniscayaan. Tugas MT untuk menetralisasi keniscayaan itu melalui bahasa humor, walaupun kata-kata humor itu bercorak ironis-metaforik.

(b) Kalau terkenal, itu tidak harus berkualitas. Anda masuk kandang macan, audien terdengar tertawa, yang sedang marah sama istrinya.

Kata kandang macan sebagai ilustrasi berfungsi memberi kemudahan kepada mitra tutur untuk mengerti dan menyadari perbedaan antara ingin dikenal dan ingin terkenal. Ingin terkenal tidak harus berkualitas karena "diterkam macan yang sedang marah pada istrinya" juga bisa terkenal karena kejadian itu bernilai berita sehingga bisa menjadi berita menarik bagi media massa. Pesan tersirat itu disampaikan MT walaupun tidak dituturkan secara verbal. Demikian pula nomina berikut ini.

(c) Bayangkan kalau kita punya anak umur 2 tahun baru mandi bau minyak telon. Bagaimana suara kita? "Hei, apa kabar?” Coba! Gunakan suara itu untuk bicara dengan istri kita walaupun dia tidak kecil lagi. Audien terdengar tertawa.

Nomina minyak telon,juga sebagai ilustrasi tentang "resep" menjaga hati agar tetap berada di jalan yang lurus. MT mengajak/menasihati mitra tuturnya untuk berbicara atau bertutur seperti "suarasuara" ketika kita menyapa bayi usia 2 tahun, selesai mandi, wangi seperti wanginya minyak telon. Kita bisa merasakan tentang pilihan-pilihan kata, nada suara, dan gaya bahasa yang digunakan ketika berkomunikasi dengan balita seperti itu. Perasaan suka, senang, riang, simpati, positif, dan optimis terhadap si balita akan terekspresikan dan ikut mewarnai bentuk dan gaya tuturannya. MT menasihati agar menggunakan gaya tutur dengan suara seperti itu, misalnya ketika kita berkomunikasi dengan isteri.
MT dalam acara MTGW menggunakan bahasa humor dengan unsur nomina seperti yang dicetak tebal dalam cuplikan (a, b, c). Kandungan makna dan pesannya padat. Banyak informasi yang disampaikan kepada audien walaupun tidak dituturkan secara lisan atau tulisan. Walaupun makna dan maksud yang terkandung dalam nomina itu tersirat dan padat, tetapi audien terlihat dan terdengar merespon dengan senyum, tawa, bahkan tepuk tangan pertanda mereka mengerti maksudnya. Penutur MT berpraanggapan bahwa mitra tuturnya mengerti apa makna dan maksud pesan tersirat dalam nomina pada tuturan (a), (b), dan (c).

Pilihan kata memiliki peranan penting dalam penggunaan bahasa di ruang publik seperti di Metro TV. Dampaknya cepat dan serempak dapat menjadi pertimbangan bagi MT. Hal ini didasarkan pada katakata yang dipilih dan digunakan dalam bahasa humornya pada acara MTGW tidak ditemukan yang bernuansa kasar, tetapi yang terlihat dan terdengar, audien mitra tuturnya sering tersenyum, tertawa, dan tepuk tangan. Hal itu sebagai implikasi bahwa katakata yang dipilih dan digunakan MT sesuai dan serasi dengan yang diharapkan mita tuturnya. Keraf menyatakan bahwa penggunaan kata, kalimat dan gaya bahasa yang sesuai konteks merupakan wujud dan cerminan dari pemanfaatan strategi pragmatik.

Strategi pragmatik, pilihan kata, tertawa, dan kesantunan berkorelasi dalam tindak tutur acara MTGW. Tuturan MT yang berupa ragam humor membuat jelas tindakan lokusi, yaitu isi tuturan yang diungkapkan kepada audiennya. Dengan tindakan lokusi itu justru akan menjadi dasar tindakan illokusi. Tindakan MT dalam mengatakan sesuatu dalam ragam humornya diarahkan sesuai dengan tanggung jawabnya sebagai motivator. 


\section{B. Penyerasian Pilihan Kalimat dengan Humor} dan Kesantunan sebagai Strategi Pragmatik

Penelitian ini menemukan tiga penggunaan kalimat, yaitu kalimat deklaratif, imperatif dan interogatif. Dalam kajian pragmatik, kalimat tidak semata-mata berfungsi untuk menyampaikan informasi atau makna kalimat, melainkan juga maksud penutur yang tersirat pada tuturannya. Dalam kajian pragamtik, kalimat dimaknai dan dibahas berdasarkan maksud pelaku tutur.

Acara MTGW di Metro TV dengan topik yang bermacam-macam, tetapi pesannya berkisar tentang penilaian, kritikan, ajakan, dan tawaran solusi. Dalam penggunaan kalimat deklatarif, MT menyampaikan isi tuturan penilaian, kritikan, bahkan kecaman. Akan tetapi semuanya memuat dan menuturkan kebenaran yang menjadi tanggung jawabnya sebagai motivator. Ia tidak ragu-ragu atas kebenaran isi tuturannya. Hal ini sesuai dengan katakata yang digunakan dalam kalimat deklaratif yang mudah dipahami, jelas, tegas, bahkan keras, tetapi daya jenaka dan kesantunnya dipakai sebagai pelunaknya. Contoh:

\section{Teks 5}

\begin{abstract}
Mantanku Penyiksaku. Kalau tidak ada mantan tidak tersiksa ya? (a) Waktu pacaran menderita karena pacar, setelah putus kebahagiaan mantan menyiksa kita. Audien terdengar tertawa. Itu maksudnya apa? (b) Waktu bersama-sama tersiksa, setelah terpisah memperhatikan untuk tersiksa. (c) Kita ini tidak bisa jauh dari sikap kita sebagai bayi. (d) Bayi itu kalau mainannya, mantannya dibuang, diambil bayi lain, marah. Kita sama. (e) Sudah putus, tapi tidak ikhlas melihat sahabat kita mengambil mantan kita. Audien terdengar tertawa. Ya, seperti ada hak guna bangunan, gitu. Itu, untuk para mantan. Audien terdengar tertawa.
\end{abstract}

Kalimat yang dicetak tebal pada Teks 5 merupakan deklarasi/pernyataan MT, yang bersifat penilaian, kritikan, dan nasihat. Yang dinilai, dikritik, dan dinasihati MT adalah kita. Setiap manusia dinilai tidak ikhlas jika mantannya diambil orang lain walaupun orang lain itu sahabatnya. Tuturan deklaratif-penilaian itu menggeneralisasi. Bentuk penilaiannya adalah mengontraskan dengan menggunakan kata penghubung setelah. Kita diibaratkan bayi dalam menyikapi mantan, dan mantan ibaratkan seperti mainan bayi.

Teks 5 berbentuk deklaratif-penilaian, kritikan, dan nasihat maka apakah penilaiannya memuji atau mengecam? Penilaian yang tersirat pada kalimat tutur deklaratif tersebut mengecam atau mengkritik, yang dikritik adalah kita manusia; tidak mengkritik orang per orang. Kata-kata yang berkonotasi kritikan dan kecaman adalah kata bayi, tidak ikhlas, marah, dan hak guna bangunan.

Pemakaian kalimat tutur deklaratifpenilaian, kritikan dan kecaman dengan memanfaatkan bentuk pengontrasan atau perlawanan dengan penanda hubungan waktu setelah dan pengibaratan dengan kata bayi, mainan,hak guna bangunan, dan tidak ikhlas dapat membuat muka atau citra diri mitra tuturnya terancam.

Tuturan deklaratif pada Teks 5 menggunakan strategi bertutur secara blak-balakan, tanpa basa-basi, jelas, tegas, jenaka sekaligus gaya pengontrasan dan pengibaratan maka muka audien mitra tuturnya dapat terancam. Skala keterancamannya relatif rendah karena (1) tuturan deklaratif-penilaian, kritikan, dan kecaman itu tidak ditujukan pada audien mitra tuturnya secara orang per orang. Penilaian dan kecamannya ditujukan pada kita sebagai manusia sehingga bersifat general-universal, (2) tuturan tersebut sebagai pembukaan, apalagi topik acaranya cukup provokatif, yaitu "Mantanku Penyiksaku". Setiap penutur, termasuk MT berusaha membuka dengan menarik dan menyenangkan bagi audiennya. Justru dengan model dan bentuk kalimat tutur seperti itu di tahap pembukaan acara akan terasa kejenakaannya atau humornya dan audien memang 
terlihat dan terdengar tertawa pertanda mereka senang.

Dalam penggunaan kalimat imperatif juga demikian, MT ingin benar-benar membuat isi tuturan yang berupa perintah ajakan maupun larangan yang harus segera dilakukan oleh mitra tuturnya. Namun, kalimat imperatif yang dipilihnya tidak selalu berupa kalimat perintah secara langsung, melainkan ada kata lain yang menyebabkan kalimat tersebut menjadi kalimat perintah tak langsung. Pemilihan strategi ini menaati kaidah kesantunan dan kerja sama, yaitu memberi keuntungan kepada orang lain sebanyak mungkin. Dengan tidak menyuruh secara langsung, MT menjaga harga diri audien dan juga berhasil meyakinkannya untuk bisa segera berubah. Contoh:

\section{Teks 6}

Dalam hal keindahan, Anda bertanggung jawab penuh. (a) Indahkan suara Anda. Ada suara yang enak didengar. Bayangkan kalau kita punya anak umur 2 tahun baru mandi bau minyak telon. Bagaimana suara kita? "Hei, apa kabar?" Coba! (b) Gunakan suara itu untuk bicara dengan istri kita walaupun dia tidak kecil lagi. Audien terdengar tertawa. Ada suara yang kita gunakan kalau kita ditagih orang yang maksa terus. (c) Jangan gunakan suara itu. (d) Kalau begitu jadilah pribadi yang menjadi bibit dari keindahan di kehidupan Anda.

Teks 6 merupakan cuplikan tuturan MT pada acara MTGW. Topiknya adalah "Jalan Menuju Kecemerlangan". Teks tersebut merupakan jawaban MT terhadap pertanyaan: Bagaimana menjaga hati agar berada di jalan lurus? MT menyamakan jalan lurus dengan kata keindahan. Perintah atau suruhan dalam Teks 6 terdapat pada kata indahkan dalam kalimat imperatif, "Indahkan suara Anda" dan kata gunakan dalam kalimat, "Gunakan suara itu untuk bicara dengan istri kita walaupun dia tidak kecil lagi”. Audien terdengar tertawa. Kalimat tersebut bernilai humor karena penggunaan ilustrasi seperti,

\footnotetext{
"Bayangkan kalau kita punya anak umur 2 tahun baru mandi bau minyak telon. Bagaimana suara kita? "Hei, apa kabar?" Coba! Gunakan suara itu untuk bicara dengan istri kita walaupun dia tidak kecil lagi”.
}

Pesan MT dalam kalimat perintah konseptual itu kepada audiennya: "Gunakan suara itu untuk bicara dengan istri kita walaupun dia tidak kecil lagi”, “...jadilah pribadi yang menjadi bibit dari keindahan di kehidupan Anda”. Pesan general-konseptual tersebut disampaikan MT dengan menggunakan ilustrasi: balita, mandi, minyak telon.

Penutur MT berpraanggapan bahwa audien mitra tuturnya mengerti maksud dari ilustrasi itu. Balita usia 2 tahun, dimandikan, wangi minyak telon sehingga ia terlihat segar, bersih, lucu, wangi, dan menggemaskan. Kita oleh MT diminta atau disuruh membayangkannya, kira-kira suara yang kita gunakan untuk menyapa balita imut-imut dan wangi itu suara indah untuk didengar dan dirasakan atau sebaliknya? Audien mitra tuturnya hanya diberi contoh sapaan “Hai, apa kabar?” Padahal spektrum pesan dalam kalimat perintah konseptual berupa ilustrasi itu relatif padat makna. Bagaimana dengan penggunaan kalimat interogatif?

Dalam penggunaan kalimat interogatif, MT menggunakannya secara retoris. Ia tidak sedang bertanya, melainkan menekan, meyakinkan, dan menguatkan kebenaran yang disampaikannya. Dalam kajian sintaksis, kalimat interogatif berfungsi untuk menanyakan sesuatu. Namun, dalam perspektif pragmatik, kalimat interogatif tidak selalu berfungsi menanyakan, juga bisa menegaskan kebenaran atas isi tuturan yang ia anjurkan kepada audiennya. Dengan demikian, ada perbedaan fungsi kalimat dalam kajian pragmatik ini. Tipe kalimat interogatif yang digunakan MT seperti kalimat yang dicetak tebal dalam teks berikut ini.

Teks 7

Salah satu sebab pernikahan yang menyiksa adalah kasihan. Karena kasihan you menikah. Banyak sekali pernikahan yang tersiksa karena itu, bukan cinta tapi kasihan. Apakah dia kasihan, Ibu menua, berharap - Ibu belum tua - tapi Ibu menua, berharap kepada Anglingdarmo ini? Ayo. Audien terdengar tertawa. 
Kalimat interogatif (cetak tebal) yang digunakan MT untuk meyakinkan dan menekan salah seorang audien acara MTGW yang sulit melupakan mantannya walaupun ia sudah dihianati beberapa kali. Karena mantannya sudah banyak berkorban maka ia merasa masih kasihan untuk melepaskan mantannya dengan mudah dan cepat.

Penekanan terhadap audien tersebut juga dilakukan MT dengan cara meminta pendapat audien yang hadir di studio Metro TV. Kalimat interogatif yang digunakan MT untuk bertanya tentang bagaimana seharusnya ia bersikap terhadap mantannya adalah seperti,

\section{"Lakukan yang baik bagimu atau kamu tidak baik bagi siapa pun. Apa yang baik bagi Anda? Siapa bilang "ya, terima dia?" Audien terdengar menjawab huu dan terdengar mereka tertawa. Siapa bilang lupakan? Audien serempak menjawab, lupakan! Audien terdengar tertawa."}

Kalimat interogatif seperti yang dicetak tebal itu berfungsi untuk memberikan penekanan lanjutan agar ia dapat memutus hubungan dengan mantannya. Oleh karena ketika MT bertanya pada dia dan jawabannya: "Masih sedikit ada rasa cinta", "Belum bisa memutuskan Pak" maka MT meresponnya dengan kalimat tutur, "Lihat ya, dia bilang apa jawabannya tadi? Belum bisa memutuskan, coba lihat itu. Saya melihat wanita yang tidak menghormati dirinya sendiri, oke? Apa nasihat Anda?" (kepada laki-laki di sebelahnya yang juga diminta naik panggung untuk diwawancarai MT).

Jadi, kalimat interogatif itu difungsikan untuk menekan atau mendesak mitra tutur agar mengikuti nasihat atau ajakan-ajakan MT; bukan karena MT ingin meminta jawaban ya/tidak atau informasi mengenai sesuatu atau seseorang.

\section{Penyerasian Pilihan Gaya Bahasa dengan Humor dan Kesantunan sebagai Strategi Pragmatik}

Gaya bahasa merujuk pada penggunaan majas. Majas yang digunakannya berupa figuratif. Fungsi gaya bahasa tersebut adalah untuk menjadikan tuturan lebih menarik dan memiliki makna yang dalam. Ratna (2009) menyatakan bahwa energi yang mendorong penulis untuk menulis dan pembaca untuk membaca adalah gaya, cara-cara penyajian secara keseluruhan, baik penyajian bentuk maupun isi, gaya bahasanya, termasuk majas. Dalam konteks ini, pendengar atau mitra tutur akan terus mendengarkan penutur dalam suatu tidak tutur karena gaya bahasa yang dipilihnya.

Gaya tuturan MT dalam acara MTGW bersifat dinamis, menyerasikan dengan suasana acara dan respons (verbal dan nonverbal) yang terjadi ketika komunikasi interpersonal berlangsung. Dalam konteks tertentu, MT menggunakan gaya tuturan langsung tanpa basa-basi, terbuka, terang-terangan. Gaya tuturan semacam ini digunakan MT ketika ia berdialog langsung dengan audiennya secara orang per orang. Dialog antara keduanya tidak seimbang, MT lebih dominan dalam menyampaikan isi tuturannya. Hal ini karena sesuai tanggung jawabnya sebagai motivator untuk melakukan tindak tutur berupa penilaian-penilaian, kritikan-kritikan tegas, jelas, terang-terangan, disertai kata, kalimat dan gaya bahasa yang merangsang humor tapi tetap dalam batas-batas kesantunan.

Strategi gaya tuturan humor dan dengan derajat kesantunan yang sesuai dapat menciptakan suasana persahabatan dan keriangan. Maksudnya, acara MTGW yang dilakukan dengan tindak tutur humor yang pantas dan santun dapat berakibat positif bagi audien mitra tuturnya, misalnya mereka terlihat dan terdengar tertawa riang atau senang.

Strategi gaya tuturan tanpa basa-basi dengan isi tuturan penilaian, kritikan, larangan yang nadanya 
bervariasi dan berkombinasi antara jelas, tegas, keras, sinis, dengan lucu dan santun. Varian-varian bentuk gaya tuturan langsung yang dapat melunakan gaya tuturan keras digunakan MT dengan cara menyapa lawan tuturnya dengan tuturan humor dan dengan sapaan santun atau hormat seperti bapak dan $i b u$.

Penutur MT dalam acara MTGW selain menggunakan gaya tuturan langsung, juga menggunakan strategi gaya tuturan tidak langsung, mencerminkan bahwa MT seperti memposisikan sebagai motivator yang perlu memiliki ragam gaya tuturan yang sesuai dengan isi tuturan dan profil mitra tuturnya. Otoritas sebagai motivator diperlihatkan MT melalui gaya tuturan nasihat secara jelas, tegas, dan kadang-kadang keras, tetapi "dikemas" dengan tuturan humor dan batas-batas kesantuan. Misalnya, MT menggunakan gaya tuturan berupa pertanyaan retoris yang bernada humor sehingga terjadi pelunakan efek perlokusi yang dapat mengancam harga diri/muka mitra tuturnya.

MT dalam acara MTGW juga menggunakan gaya tuturan secara tidak langsung. Maksudnya, tidak semua tuturan yang digunakan MT dalam ragam bahasa humor pada acara MTGW mengandung makna dan pesan denotatif, objektif, dan polos. MT juga menggunakan strategi gaya tuturan tidak langsung, tapi santun dan jenaka ketika ia memberikan alasan dan penjelasan terkait dengan kritikan, penilaian, larangan, dan perintah MT kepada mitra tuturnya. Gaya tuturan humor tidak langsung itu pada umumnya berupa ilustrasi metaforik atau figuratif. Tujuan penggunaannya adalah memberikan informasi yang padat makna, padat pesan, dan penguatan pengaruh perlokusi kepada mitra tuturnya.
Gaya tuturan tidak langsung yang digunakan MT dengan cara pemanfaatan gaya tutur ironi (batu bata sebagai perumpamaan orang beragama tapi tidak berfungsi sebagai hadiah bagi lingkungannya), metafor, ungkapan berlebihan (mata lebar sebagai perumpamaan dari kadar riang gembiranya jika mendapat hadiah), praanggapan (repot-repot tapi sini-sini, maksudnya sudah sama-sama dapat dimengerti oleh penutur dan petutur), pertanyaan retorik, ungkapan berlebihan yang memberikan kesan lucu atau humor. Strategi gaya tuturan tidak langsung, tapi santun dan humor pada umumnya berupa ilustrasi itu terdapat pada tuturan yang mengandung pesan genaral-konseptual sehingga isi tuturan tersebut tidak ditujukan pada petutur tertentu tapi pada umum

\section{Kesimpulan}

Satuan lingual kata, kalimat, gaya bahasa, humor, dan kesantunan digunakan MT secara serasi dalam ragam bahasa humor acara MTGW di Metro TV. Penyerasian antara tuturan (kata, kalimat, dan gaya bahasa), humor, dan kesantunan mencerminkan realisasi penggunaan strategi bertutur, baik lokusi, ilokusi, dan perlokusi. Dalam ragam bahasa humornya, MT memilih dan menggunakan pronomina persona yang mencerminkan fungsi membentuk persahabatan dengan mitranya; menggunakan adjektiva yang mencerminkan penilaian, kritikan, larangan, dan ajakan terang, tegas, keras tapi dilunakkan dengan nada humor dan santun.

Pilihan dan penggunaan kalimat dalam ragam bahasa humor juga serupa. Kata-kata yang dipilih dan digunakan dalam ragam humor menjadi unsur pembentuk kalimat. Oleh karena itu, dalam ragam 
bahasa humor terdapat keterkaitan secara serasi antara penggunaan kalimat (deklaratif, imperatif, dan interogatif) dengan humor dan kesantunan.

Pilihan dan penggunaan kalimatnya mencerminkan realisasi strategi bertutur, baik lokusi, ilokusi, dan perlokusi. MT menggunakan strategi lokusif dan ilokusif dalam mengatur, memilih, dan memproduksi setiap kata dan kalimat sehingga efek perlokusi tuturan humor menghasilkan respon senyuman, tawaan, dan tepuk tangan audien mitra tuturnya.Piliha gaya bahasa dalam ragam humor juga berkaitan secara serasi dengan kesantunan. Gaya tuturan langsung atau terang-terangan dan gaya tidak langsung atau figuratif dikombinasi (diserasikan) dengan pilihan kata dan kalimat yang merangsang humor secara serasi dan santun. Pilihan dan penggunaan gaya bahasanya mencerminkan realisasi strategi bertutur, baik lokusi, ilokusi, dan perlokusi.

\section{Saran}

Penelitian dalam ranah pragmatik sangat menarik dan penting untuk terus ditindaklanjuti oleh para peneliti bahasa. Banyak sekali model tuturan yang berkategori praktik baik digunakan oleh tokoh agama/pedakwah, tokoh masyarakat dan pemimpin yang perlu diteliti secara deskriptif-kualitatif. Hasil penelitiannya bermanfaat bagi masyarakat pengguna dan pembina bahasa, juga dapat memperkaya khasanah ilmu dan disiplin pragmatik.

Penelitian ragam bahasa humor sangat menarik untuk terus dilakukan karena bahasa humor merupakan manifestasi keterampilan berpikir tingkat tinggi. Bagaimana satuan lingual kata, kalimat, dan gaya bahasa dalam suatu peristiwa tutur berkorelasi dengan senyuman, tawa, dan tepuk tangan mitra tuturnya, dan itu sebagai "bukti" implementasi strategi pragmatik. Faktor kredibilitas (dipercaya, keahlian, dan kekuasaan) memang dapat menjadi salah satu faktor signifikan adanya korelasi tuturan dengan senyuman dan tawaan. Akan tetapi, karena kredibilitas itu hanyalah persepsi publik sehingga jika sang penutur tidak dapat merawatnya maka sangat berpeluang kredibilitas untuk menurun dalam tingkat bawah. Pengalaman dan kompetensi pragmatik meruapakan bekal vital memiliki strategi pragmatik. Akan tetapi, jika kredibilitasnya "jatuh" maka strategi pragmatik menjadi "tumpul" sehingga tidak mudah untuk mempengaruhi dan menyakinkan mitra tuturnya. Dalam hal ini juga menarik untuk diteliti.

\section{$\underline{\text { Referensi }}$}

Alwi, Hasan, dkk. 2003. Tata Bahasa Baku Bahasa Indonesia. Jakarta: Balai Pustaka.

Anastasya, Sicillia. 2013. "Teknik-Teknik Humor dalam Program Komedi di Televisi Swasta Nasional Indonesia.” Jurnal E-Komunikasi, V01.I, No.1 Tahun 2013.

Baskoro, B.R. Suryo. 2014. "Pragmatik dan Wacana Korupsi”. Jurnal Humaniora, Vo.26, No1 Februari 2014: 74-83.

Brown, Penelope dan Stephen C. Levinson. 1987. Politeness: Some Universals in Language Usage. Cambridge: University of Cambridge Press.

Chaer, Abdul. 2010. Kesantunan Berbahasa. Jakarta: Rineke Cipta.

Dardjowidjojo, Soenjono. 2012. Psikolinguistik Pengantar Pemahaman Bahasa Manusia. Jakarta: Yayasan Pustaka Obor Indonesia.

DeVito, Joseph A. 1997. Human Communication. (Komunikasi Antarmanusia). Penerjemah Agus Maulana. Jakarta: Professional Books.

Demjén, Z. (2016). Laughing at cancer: Humour, empowerment, solidarity and coping online. Journal of Pragmatics, 101, 18-30. https://doi.org/10.1016/j.pragma.2016.05.010

Gunarwan, Asim. 1997 a."Tindak Tutur Melarang di dalam Bahasa Indonesia di Kalangan Penutur Jati Bahasa Jawa". Linguistik Indonesia. Tahun 15. No.1 dan 2. Juni dan Desember 1997. Hlm.3.

Keraf, Gorys. 2000. b. Diksi dan Gaya Bahasa. Jakarta: Gramedia Pustaka Utama.. 
Rakhmat, Jalaluddin. a. Psikologi Komunikasi. Bandung: Remaja Rosdakarya.

Rakhmat, Jalaluddin.1992. b. Retorika Modern Pendekatan Praktis. Bandung: PT. Rosdakarya.

Ratna, Nyoman Kutha. 2009. Stilistika Kajian Puitika Bahasa, Sastra, dan Budaya. Yogyakarta: Pustaka Pelajar

Sinkeviciute, V., \& Dynel, M. (2017). Approaching conversational humour culturally: A survey of the emerging area of investigation. Language and Communication. https://doi.org/10.1016/j.langcom.2016.12.001

Sudaryanto. 1993: Metode dan Aneka Teknik Analisis Bahasa Pengantar Penelitian Wahana Kebudayaan secara Linguistis. Yogyakarta: Duta Wacana University Press.

Tarjana, 2016. "Penggunaan Bahasa dalam Perspektif Pragmatik dan Implikasinya bagi Peningkatan Kualitas Generasi Muda di Indonesia." Naskah pidato pengukuhan sebagai Guru Besar di Fakultas Sastra dan Seni Rupa UNS, 6 April 2016.

Yule, George. 2006. Pragmatics (Pragmatik). Penerjemah Indah Fajar Wahyuni. Yogyakarta: Pustaka Pelajar.

Yuniawan, Tommi. 2005. “Teknik Penciptaan Asosiasi Pornografi dalam Wacana Humor Bahasa Indonesia.” Jurnal Humaniora, Vol.17, No.3, Oktober 2005 